I884. Dalton, W. H., Strahan, A., and Cark, W. D.- " Report of Excursion to Lincoln and the Railway Cuttings between Lincoln and Louth." Proc. Geol. Assac., vol. viii, p. 383.

1885. JUKES-Browne, A. J.- "The Boulder Clays of Lincolnshire." Quart. Fourn. Geol. Soc., vol. xli, p. II4.

1886. StraHan, A.- "On the Relations of the Lincolnshire Barstone." Quart. Fourn. Geol. Soc., vol. xlii, p. 486.

I887. JUKEs-Browne, A. J.- "The Geology of East Lincolnshire." Mem. Geol. Survey to Sheet 84 .

I888. Strahan, A.-"On the Country round Lincoln." Mem. Geol. Survey to Sheet 83 .

I888. HILL, W.-"On the Lower Beds of the Upper Cretaceous Series in Lincolnshire and Yorkshire." Quart. Fourn. Geol. Soc., vol. xliv, p. 334 .

1895. WooDWARD, H. B.- "The Jurassic Rocks of Great Britain," vol. v, p. 286 , et seq. Mem. Geol. Survey (has a good bibliography).

1896. LAMPLUGH, G. W.-."On the Speeton Series in Yorkshire and Lincolnshire." Quart. Fourn. Geol. Soc., vol. lii, p. I79.

\title{
EXCURSION TO WOLDINGHAM.
}

\author{
Saturday, May 6Th, Ig05. \\ Director: W. Whitaker, B.A., F.R.S., F.G.S. \\ (Report by N. F. Robarts, F.G.S.)
}

THE excursion, which it was arranged should be conducted by Mr. W. Whitaker, in order to visit some outliers of Lower Eocene Beds upon the North Downs, was unfortunately deprived of his guidance, over ground the geology of which he has made his own, owing to the severe illness of a member of his family. $\mathrm{Mr}$. Whitaker was, however, able to meet the members as they passed through the station at South Croydon, and let them know that he had arranged with Mr. N. F. Robarts, F.G.S., to guide them over the route he had intended to take them. On arriving at Woldingham, the party was found to number thirty, including three or four members of the Croydon Natural History and Scientific Society, whom Mr. Whitaker had invited to join the excursion.

The Director first led the party almost as far as Bughill Farm, the point at which the members of the Association had seen the source of the flow of the Croydon Bourne at the excursion of March 12 th, I 904 , where he took the opportunity of saying a few words upon the origin of the Bourne flow for the benefit of those members who had not been present at the previous excursion. Retracing their footsteps a short distance, the Director led the party up a dry chalk valley, the north side of which they ascended, gaining a height of about $700 \mathrm{ft}$., from whence was obtained a good view of the chalk tableland of the Surrey part of the North Proc. GEol. ASSOC., Vol. XIX, PART 3, Ig05.] 
Downs, intersected with numerous dry valleys. Descending into another dry chalk valley, noticing on the way numerous neolithic flakes, amongst which were found one or two rude scrapers, the party ascended the north side of this second valley to a small chalk pit which appeared almost unfossiliferous, although fragments of Inoceramus were noted. The chalk was much disturbed and jointed, whilst some nodular blocks were noticed lying in the pit, but could not be traced in situ. The zone was therefore indeterminable, although probably in Lower Chalk. A heavy wash of Tertiary pebbles from the hill above covered the upper part of the pit. Still further ascending Nore Hill, the party reached the gravel pits in Blackheath pebble beds, which latter appeared to overlie and partly to fall into pipes in the chalk, containing sands of Oldhaven or Woolwich and Reading beds, in one place hardened into a soft sandstone, together with a few greenish subangular flints at the sides of the pipes, which were probably derived from the remains of the base of formerly existing Thanet Sand, but no other traces of this bed were apparent. 'The sands and pebbles appeared entirely unfossiliferous, but the latter were in some places hardened into conglomerate by oxide of iron, which gave the beds a strong pinkish-red colour. Messrs. Robarts and $\mathrm{H}$. W. Monckton made a few remarks upon the section, the former pointing out the small size of the pebbles. The walk was then continued through Slines Oaks to the wellknown section in Blackheath pebbles at Worms Heath. Here very similar features were observed, but the bed was thicker, the section showing a face of some $60 \mathrm{ft}$. in depth, whilst the pebbles were larger, and the ferruginous conglomerate lay in very hard and large masses.

There happened to be no chalk visible, all the sides of the pipes or pillars having been cut away, but pockets of sand and sandstone were seen with green-coated flints, showing that probably these sands were the contents of pipes in the chalk; indeed, as pointed out by the Director, it was possible that the whole pit was part of a very large pipe.

The Director again called the attention of the party to the details of this, the principal outlier of Blackheath pebbles on the crest of the Downs, and to the occurrence of allophane (a hydrous silicate of alumina) in parts of the pit, and to a small bed of subangular flints overlying the pebbles in the highest part of the pit. The party then crossed on to the mounds on Worms Heath, marked as Ancient Camp on the Ordnance Map, about which the Director made a few remarks, pointing out that they were probably only old gravel workings, and at the same time gave some information respecting a prehistoric camp lying a little to the north.

This concluding the geological work of the afternoon, Mr. H. W. Monckton, Vice-President, proposed a hearty vote of thanks 
to the Director, which, having been duly acknowledged by $\mathrm{Mr}$. Robarts, the members walked about three miles, passing a large chalk pit in the Lower Chalk, to the coffee-house at Upper Warlingham Station, where they partook of a substantial tea, and returned to London by the $6.5^{8}$ p.m. train.

\section{EXCURSION TO READING AND CAVERSHAM.}

Saturday, May i3TH, Ig05.

Directors: H. W. Monckton, V.P.L.S., F.G.S. AND

O. A. Shrubsole, F.G.S.

Excursion Secretary: H. KIDNER, F.G.S.

(Report by THE DIRECTORS.)

STARTING from Reading Station at about half-past two in the afternoon a party of twenty-three crossed the Thames into Oxfordshire at Caversham.

After passing through the village, Mr. Shrubsole drew attention to a section in the bank at the side of the Peppard Road. It showed gravel resting on Chalk at a level of $\mathrm{I} 68 \mathrm{ft}$. O.D. He said that the gravel belongs to a terrace which has yielded flint implements and also remains of the Mammoth. The gravel is coloured Plateau Gravel on the new edition of the Geological Survey Map. It is however, within the valley. Mr. Monckton remarked that owing to the way in which the sheets of gravel extended from the plateaux into the valleys in the district it had been found convenient to colour as Plateau Gravel several patches and terraces which, though in the valley, were above the bottom of the valley, and seemed more closely connected with the gravel on the hill top than with that at the bottom of the valley. He mentioned the Grovelands terrace as a good example.

Near the top of the hill the party passed on to the Emmer Green Outlier of Eocene Beds. This outlier is to a large extent covered by gravel, and a pit was visited at a level of $269 \mathrm{ft}$. O.D. The gravel seemed to be about io ft. thick, was roughly stratified, and of a reddish colour. A few pebbles like those of the Triassic Pebble Beds were noticed, but they did not seem common.

Mr. Shrubsole said that occasionally implements had been found at this place.

Leaving the pit the party halted at a point from which a fine view of the valley of the Thames and the surrounding hills was obtained, and $\mathrm{Mr}$. Monckton made some remarks on the geological history of the district. He said that the oldest formation at the surface of the ground before them was the Chalk, a bed of 